\title{
Socio-Economic Implications in Mitigating Housing Challenges and Development in Ikpoba-Okha Local Government Area, of Edo State, Nigeria
}

\author{
Omoyibo Kingsley Ufuoma (Ph.D) \\ Odia, Osaretin Lucky \\ Department of Sociology and Anthropology, Faculty of Social Sciences, University of Benin, \\ P.M.B.1154, Benin City, Edo State, Nigeria \\ Phone: +234-805-9253070/+234-803-35424-67 \\ Email: odialucko@yahoo.com; ufuomaomoyibo@hotmail.com
}

\section{Doi:10.5901/ajis.2014.v3n1p433}

\section{Abstract}

This paper examines the Socio economic implications in mitigating housing challenges in Ikpoba-Okha Local Government Area of Edo State, in Nigeria. The population of study include, housing developers, intending developers and tenants in the area of study. A sample of 360 respondents were drawn from 12 selected urbanizing centers in the study area. The instrument used for the study is the questionnaires and the analysis adopted is the simple percentages. The study revealed that the investment prowess of housing developers, prospective developers and tenants is low due to cost of housing. This was the view of 80 percent of the respondents, 17.5 percent of the respondents were opposed to this view, while 2.5 percent were undecided. The study further revealed that 72.5 percent of the respondents were of the view that having efficient and affordable housing in place will enhance development; 15 percent of the respondents were opposed to this view while 10 percent of the respondents were undecided. The paper recommends that government should step up efforts in housing scheme, acquiring land and appropriating same to would be developers at a reduced rate, and investment on the production of local building materials. Also, that government should provide agricultural incentives which will on the one hand, improve on living conditions in rural areas and on the other hand, boost their investment capabilities thereby, helping to stem incidence of rural urban drift and enhancing national development.

Keywords: Challenges, Development, Essentialism Theory, Housing, Investment, Mitigation

\section{Introduction}

The absence of housing facility for a man steps up a world of illusion in course of life and thus hampering his ability to contribute maximally towards societal development. Giving this as fact, achieving the increasing quest for housing development needs to the people requires a compact synergy of the critical stockholders in the housing industry, namely the government, corporate organizations and individual developers. According to Stone (1991) housing is unique among consumer goods in its pervasive economic, social and psychological significance. Housing supply level in Nigeria today which is at a high level deficit is due to the passive effort of the government towards housing facility delivery. According to Thompson (2006) housing generally in Nigeria has not ranked high on the scale of priorities for social spending and state governments have tended to rely upon local authorities to meet the problem. Housing facility seekers over the years have been left with no option than to seek ways to providing themselves housing needs.

Efforts by individuals in mitigating their housing challenges in Nigeria, has overtime served as a source of drill on their financial resource. The cost of meeting housing needs either on payment for rent or developing one, grossly affects savings which hitherto is the panacea for investment on economic activities.

Other parts of the world, where appreciable level of housing service delivery has been achieved are those whose government and agencies have contributed immensely towards its accomplishment. However, in Nigeria, the government has complicated the housing issue on the basis of its 'urban bias' development policies. Overbearing neglect of rural areas where the people have suffered lack of basic amenities over time and under pressure to shift base from usual places of abode in order to mitigate the inadequacies which they hitherto suffered. Inclusively, agriculture which is the main economic backbone to the rural people is yet to enjoy the desired amount of support from the government. Thus, serving as a 'push' rather than being a 'pull factor' to the rural areas. The implication of these therefore, is upsurge in population of the few urban centres where housing becomes utmost necessity that must be met. Whereas on the reverse, 
more and more houses, are experiencing abandonment and dilapidation, in the rural areas due to 'rural-urban' drift.

Though the average income level of most Nigerians is known to be low and thus reduces the capability of most people to own houses of their own, and as well invest in other productive ventures, the other sure and viable source of investable fund is capital inflow from Nigerians in the Diaspora. In the wake of the inadequacies in the housing sector, such inflows are skewed to the development of residential homes. It is also a known fact that other associated cost relating to housing development, such as, community development fees, electrification, road construction and maintenance, water sourcing, etc., further contribute to economic and investment powerlessness of the developers. Other housing challenges in Nigeria include: high cost of land acquisition, high cost of rent, poor housing incentives by government, unfavorable credit system etc.

Thus, this paper, studies the socio-economic implications in mitigating housing challenges and development in the area of study (Ikpoba-Okha).

\section{Literature Review}

Currently in Nigeria, housing supply is growing slower than housing demand. The existing mortgage banking system has not lived up to their expectation in fulfillment of its statutory obligation of making housing facility available on demand. On the other hand, the commercial banks as they currently function in Nigeria today do not favor housing development, due to high interest rate charges that are far beyond the reach of most prospective house developers. According to Duncan (2003) demand for housing will grow faster because demographic factors like population growth, household formation rates, immigration, employment growth and income growth are all going to push demand forward more rapidly.

Larsen (2010) opined that rising house prices lead to questions of sustainability, since mortgage must be financed from future incomes. In his study of the Norwegian Consumer Expenditure surveys in the period 1986 - 1998, observe that the elasticity remain surprisingly close to unity for all years. The mean over the period was 1.02. Which indicate that as incomes or total consumption increase by $1 \%$, housing expenditure also increases by $1 \%$. The outcome of this study implies that given demographic composition, a household demand for housing seems to increase proportionately with total consumption, in contrast to categories such as food and transportation. This study by Larsen concludes that if the elasticity continues to be unity, then over a period of time future housing expenditures will keep the same pace as incomes. Also Stams (2010) in a study of the role of housing in the welfare state raised these fundamental questions. What are the connection between home ownership and welfare policies? And has there been a change in these connections over time? The study observed that between 1980 and 2001 public social expenditures, public expenditures on housing and home ownership have increased in most countries. The study further observed that the long tradition of trade-off between home ownership and pensions also remain strong. Previous studies in Nigeria by Onibokun (1986) and Nubi (1991) cited in Nubi (2000) reveal that rent in our major cities is about $60 \%$ of an average workers disposable income, noting that this is far higher than the $20-30 \%$ recommended by United Nations.

Ibagere (2002) contributing, observed that Nigeria as the sixth largest oil producing nation in the World, housing problem have remained endemic and most of her people still live in houses which a United Nation Housing Expert, Charles Abrams, described as "an affront to human dignity", Ibagere contends that in this new millennium, we cannot afford to remain in the dark. To him, we must follow the rest of the world and take steps to provide shelter for the masses, the poor and low-income earners in Nigeria.

In the literature reviews, issues relating to increasing needs for housing facilities, rising cost of house acquisition and rent, the implication of these cost on income as well as the trade offs arising from the rising expenditure in meeting housing needs were raised and discussed. The literature reviewed, accepted the fact that there is an increasing need for housing facility; and revealed that housing cost is on the rise, taking substantial proportion of income leading to a cut in cost for other basic needs and a restrain in affordability power as well as savings.

\section{Theoretical Framework}

The theory adopted for this study is the essentialism theory as postulated by Martha Nussbaum (1999; 2000 and 2003) in her 10 "essential" functions required for human life. She framed these basic principles in terms of ten capabilities, i.e. real opportunities based on personal and social circumstance. The capabilities approach has been highly influential in development policy where it has shaped the evolution of the human development index (HDI) (see Alkire, 2002). This theory has been discussed extensively in philosophy and its influence has increasingly spread through the social sciences. Among these capabilities as enunciated by Nussbaum include: 
i. Life - Being able to live to the end of a human life or normal length; not dying prematurely, or before one's life is so reduced as to be not worth living.

ii. Bodily Health- Being able to have a good health, including reproductive health, to be adequately nourished, to have adequate shelter.

iii. Bodily integrity- Being able to move freely from place to place; to be secure against violent assaults, including sexual assault and domestic violence; having opportunities for sexual satisfaction and for choice in matters of reproduction.

Analyzing this assertion by Nussbaum, Nicholls (2010) sees the introduction of moderate essentialism on one framed through the capabilities and critical realism, to a theoretical interpretation of what housing represents, as both an enabling and constraining force by which these ten essential functions could be attained. Thus, make the individual live a "well lived" life. Similarly, Amartya Sen contends that functioning are crucial to an adequate understanding of the capability approach; as capability to him is conceptualize as a reflection of the freedom to achieve valuable functioning. $\mathrm{He}$ argued against excessive materialism in the evaluation of human welfare and concern for the distribution of opportunities within society. Poverty is understood to mean capability - deprivation. As it is noteworthy that the emphasis is not only on how human beings actually functions but also on their having the capability, which is a practical choice, to function in important ways if they so wish (see Alkire, 2002, 2005; Kaufman, 2006 and Anand, Hunter and Smith 2005). Development therefore, is predicated upon the enabling opportunities created by the society for its citizens in improving their capabilities and well being.

\section{Methods}

The study area is Ikpoba-Okha Local Government Area of Edo State, Nigeria. The focus of the study is on the Socioeconomic implications in mitigating housing challenges and development. Housing facility owners, tenants and prospective house owners in the study area constitute the population of this study. Ikpoba-Okha LGA is chosen, in view of the fact that majority of its communities are either Urbanized or newly Urbanizing centers while others are rural settings. 3 communities/cerntres were sampled from each of the 4 zones in the locality, making a total of 12 communities/centres. The 4 zones are Aduwawa, Oregbeni/Ohovbe, Sokponba and Evboriaria. In each of the Communities, 30 respondents were selected using purposive sampling technique. A total of 360 respondents were selected from the communities.

Questionnaire instrument was used in gathering data for the study. The questionnaire format is made up of 5 points items Likert scale. The instrument is made up of two parts, section A- demographic/biodata and section B- which contains questions designed to elicit desired responses from the respondents. The instrument was validated by two experts in the field development studies and demography. The statistical tool for analysis used in this study is the simple percentage.

\section{Findings}

\subsection{Research Question 1- Does housing development reduce investments prospects of an average developer?}

Table One: Housing Development and investment prospects of an average developer.

\begin{tabular}{|c|c|c|c|c|c|c|c|c|}
\hline Item & SA & A & DA & SD & UD & \%SA\&A & \%SD\&D & $\%$ UD \\
\hline 2 & 198 & 126 & 18 & - & 18 & 90 & 5 & 5 \\
\hline 3 & 180 & 72 & 72 & 36 & - & 70 & 30 & - \\
\hline Total & 378 & 198 & 90 & 36 & 18 & 80 & 17.5 & 2.5 \\
\hline
\end{tabular}

Source: Author's field survey 2011.

80 percent of the respondents agreed that the cost of mitigating housing needs reduces the investment capabilities of the housing facility seekers, 17.5 percent disagreed while 2.5 percent of the respondents were undecided. 


\subsection{Research Question 2- Does efficient housing delivery system influence development?}

Table Two: Efficient housing delivery and national development.

\begin{tabular}{|c|c|c|c|c|c|c|c|c|}
\hline Item & SA & A & DA & SD & UD & \%SA\&A & \%SD\&D & $\%$ UD \\
\hline 6 & 108 & 90 & 18 & 72 & 72 & 55 & 25 & 20 \\
\hline 8 & 216 & 108 & 18 & - & - & 90 & 5 & - \\
\hline Total & 324 & 198 & 36 & 72 & 72 & 72.5 & 15 & 10 \\
\hline
\end{tabular}

Source: Author's field survey 2011.

$75 \%$ of respondents agreed that having efficient housing system in place can influence development. $15 \%$ of the respondents however disagreed while $10 \%$ of the respondents were undecided.

\subsection{Research Question 3- Does provision of basic amenities in urbanizing areas reduce cost of owing a house?}

Table Three: Provision of basic amenities and cost of owing a house.

\begin{tabular}{|c|c|c|c|c|c|c|c|c|}
\hline Item & SA & A & DA & SD & UD & \%SA\&A & \%SD\&D & $\%$ UD \\
\hline 1 & 216 & 126 & 18 & - & - & 95 & - & 5 \\
\hline 5 & 54 & 162 & 36 & 18 & 72 & 60 & 15 & 20 \\
\hline 10 & 162 & 90 & 54 & 36 & 18 & 70 & 5 & 25 \\
\hline Total & 432 & 378 & 108 & 54 & 90 & 75 & 15 & 8.3 \\
\hline
\end{tabular}

Source: Author's field survey 2011.

75 percent of the respondents agreed that provision of basic amenities in newly urbanizing areas will reduce the cost of owing a house, 15 percent of the respondents disagreed while 8.3 percent of the respondent were undecided.

\subsection{Research Question 4- Does provision of land to prospective developers reduce cost of owing a house?}

Table Four: Provision of land to developers and cost of owing a house.

\begin{tabular}{|c|c|c|c|c|c|c|c|c|}
\hline Item & SA & A & DA & SD & UD & \%SA\&A & \%SD\&D & $\%$ UD \\
\hline 9 & 180 & 108 & 54 & 18 & - & 80 & 20 & - \\
\hline 4 & 162 & 126 & - & 54 & 18 & 80 & 15 & 5 \\
\hline Total & 342 & 234 & 54 & 72 & 18 & 80 & 17.5 & 2.5 \\
\hline
\end{tabular}

Source: Author's field survey 2011.

80 percent of the respondents agreed that provision of land at reduce rate will help reduce the cost of owing a house, 17.5 percent of the respondents disagreed that provision of land will reduce cost of owing a house while 2.5 percent of the respondents were undecided.

5.5 Research Question 5- Does enhancement of living standard in rural areas by government reduce pressure of housing needs in urban centres.

Table Five: Enhancement of living standard in rural areas and pressure on urban housing needs.

\begin{tabular}{|c|c|c|c|c|c|c|c|c|}
\hline Item & SA & A & DA & SD & UD & \%SA\&A & \%SD\&D & $\%$ UD \\
\hline 7 & 216 & 54 & 36 & 18 & 36 & 75 & 15 & 10 \\
\hline 11 & 198 & 72 & 54 & 18 & 18 & 75 & 20 & 5 \\
\hline 12 & 216 & 90 & 36 & 18 & - & 85 & 15 & - \\
\hline Total & 630 & 216 & 126 & 54 & 54 & 78.3 & 16.7 & 5 \\
\hline
\end{tabular}

Source: Author's field survey 2011. 
78 percent of the respondent agreed that enhancement of living standard in rural areas by government will reduce pressure of housing needs in urban centers. 16.7 percent of the respondents disagreed that enhancement of living standard in rural areas by government can reduce pressure on urban housing demand. While 5 percent of the respondents were undecided.

\section{Discussion}

This study, was aimed at finding out the Socio-economic implications in mitigating housing challenges and development in Ikpoba- Okha LGA of Edo state in Nigeria. Modern societies have acknowledged the fact that housing is a basic essential to man and a function of a nation's development. The study reveal that $80 \%$ of the respondents were of the view that the cost of mitigating housing needs reduces the investment capabilities of the housing facility seekers in society. $17.5 \%$ of the respondents were opposed to this view, while $2.5 \%$ of the respondents were undecided. This findings however, implies that the ability of individual's investment in production ventures leading to composite development is hampered, due to the high cost of meeting their housing needs. A similar study by Rachel (2005) revealed that 60 percent of cost burdened households (spending at least 30 percent of their income on housing) are in the bottom fourth of the income distribution, earning up to two times the full-time equivalent of the Federal minimum wages or around $\$ 22,000$ and 84 percent of all severely cost burdened households - those spending at least 50 percent of income on house - are in this income group.

This study, also revealed that 72.5 percent of the respondents were of the view that having efficient and affordable housing in place can help influence development. 15 percent of the respondents were opposed to this view, while 10 percent of the respondents were undecided. A recent study by Voelker (2010) reveal that making transit efficient housing available across the economic spectrum (mixed use, mixed income development) will take extraordinary effort and creativity across multiple discipline neighborhood planning and education, crafting unique financing sources, developing new zoning and building type etc.

Responding to the view, whether the provision of basic amenities in urbanizing areas reduces cost of owing a house, 75 percent of the respondent accepted this view, 15 percent of the respondents opposed this view, while 8.3 percent were undecided. 80 percent of the respondents where of the view that provision of land at a reduced rate will help reduce the cost of owing a house, 17.5 percent of the respondents were opposed to this view, while 2.5 percent of the respondent were undecided. Ibagere (2002) observe that availability of land is the basis for all development and it is a major factor in housing development especially as its size and location is fixed. The demand for land for development at all times out strip its supply and its in-accessibility constitutes a great obstacle to development for both public and private sectors of the economy. Due to the complex and confusing land tenure systems in Nigeria and the need for land to be made easily available for development, the Land Use Decree was promulgated in 1978. The Decree had the best of intentions for all Nigerians, but its interpretation and implementation became a problem.

In responding to the view whether enhancement of living standard in rural areas by government can help reduce pressure of housing needs in urban centres, 78.3 percent of the respondents responded on the affirmative. 16.7 percent of the respondents opposed this view while 5 percent of the respondents were undecided. Alluding to this view, Akpan (2008) advised the government to provide land at affordable cost to developers even in area away from city centres to avoid over-crowding. He added that link roads be constructed as well as, provision of site and service infrastructures for this land such as electricity, water, roads and other basic needs to attract people to these areas. It is worthy of note that a nation that desires progress in all sectors expects to have a healthy, skilled and productive workforce who should be able to function maximally only when comfortable and affordable housing facility are made available and assured of the possibility of being able to save for the future.

\section{Conclusion and Recommendations}

The emerging economics of the world today having undergone some development challenges, were able to overcome them due to the high capabilities built in their citizens. Thus, experiencing sustainable development in any nation rest upon the productivity capabilities built and possessed by its people as development therefore, is people centered and people driven. According to Annan (2011) the newly emerging economics understand that the key to development is not charity but equitable, job-creating, and ideally green economic growth fuelled by investment in the productive sectors such as agriculture, infrastructure, renewable energy, trade, knowledge and technical skills. Government at all levels in Nigeria, should create the enabling environment which will serve as a synergy for both local and foreign investors/building 
professionals, to pull their resources and expertise together in remeding the housing challenges.

This Paper is of the view that for Nigeria, to be among the 20 most developed nations of the world by the year 2020 as envisaged, the nation must invest massively on infrastructural development which includes mitigating housing challenges. Also, investment capabilities of its people must be enhanced in order that they can contribute meaningfully towards national development.

\section{References}

Akpan, Patrick .B (2008), Low-cost Housing, an Example for Nigeria. Oct. 1, 2008.www.articlebase.com>... >Finance

Alkire, Sabina. (2002) "Dimensions of Human Development" World Development 30(2): 181-125.

Alkire, Sabina. (2005b). "Why the capacity Approach". Journal of Human Development 6(1): 115-33.

Anand, P. Hunter, G. and Smith, R. (2005). Capabilities and Well-Being, Social Indicators Research, 7 (1), 9-55.

Kofi, A. (2011). We need another Gleneagles moment. Le Figaro Publishers. Kofiannafoundation.org>Home.

Duncan, Douglas. G. (2003) Unwavering demand for housing zaps the housing bubble theory. www.bankrate.com/../20030918a1.asp.

Ibagere, O. P. (2002). The Dividends of Democracy - How far with Housing for All. A paper presented at the Delta State Government Seminar at Asaba on the National Housing Fund on $26^{\text {th }}-27^{\text {th }}$ June 2002.

Kaufman, Alexandar (2006). Capabilities Equality: Basic Issues and Problems. New York, N. Y: Routledge.

Larsen, Erling. R. (2010). What May Eventually Limit Rising Housing Prices? Evidence from Engel Elasticities and Budget Shares of Housing. Housing, Theory and Society, Vol. 27. Issue 1 March 2010 P. 75 - 108 Routledges Press.

Nicholls, C. M. (2010). "Housing, Homelessness and Capabilities. Housing, Theory and society, Vol. 27, Issue 1 March 2010. P. 23 - 41. Nubi, T. O. (2000). Housing Finance in Nigeria - Need for Re-Engineering. unilag-edu.ng/cv/4748.doc.

Nussbaum, Martha. (1993). "Non-Relative Virtues: Aristotelian Approach" in M. Nussbaum and A. Sen eds. The Quality of Life, P.242 69. New York: Oxford Clarendon press.

Nussbaum, Martha. C. (2000) "Women and Human Development: The Capabilities Approach. Cambridge University Press.

Nussbaum, Martha. C. (2003). "Capabilities as Fundamental Entitlement: Sen and Social Justice" Feminist Economics 9(2 - 3):33 - 59.

Rachel, Drew (2005). A Reality Check for Housing Affordable Advocates. The State of the Nation's Housing 2005. joint Center for Housing Studies, Harvard University Cambridge, MA Issues No. 142. July/August.

Sen, Amartya. (1993). "Capability and Well-Being" in M. Nussbaum and A. Sen, eds. The quality of Life, P. 30-53 New York: Oxford Clarendon Press.

Sen, Amartya. (2009). The Idea of Justice. Cambridge, M. A: The Belknap Press of Harvard University Press.

Stams, Mary. A. (2010). "Housing and Welfare Policy - Changing Relations? A Cross-National Comparison. Housing, Theory and Society, Vol. 27, Issue 1 March 2010. P. 64-75.

Stone, M. (1991). 8 million elderly are Shelter Poor. Shelter force, 13(3) 4

Stone, M. (1993). Shelter Poverty. Philadelphia: Temple University Press

Thomson, G. (2006) Housing. www.nationsencyciopiadis.com/Africa/Nigeria-Housing. Html 11/10/2006.

Voelker, Robert. H. (2010) Transit Efficiency: New Orientation for Real Estate Development. www.munsch.com/newsstand/articles-466 